\title{
Modeling the Economic Impacts of Increasing Diversion in Ontario's Industrial, Commercial and Institutional (IC\&I) Sector
}

\section{Calvin Lakhan*}

Department of Geography, Wilfrid Laurier University, Waterloo, Ontario, Canada

\begin{abstract}
This study examines the challenges and opportunities for increasing diversion in Ontario's Industrial, Commercial and Institutional (IC\&I) sector. The IC\&I sector is responsible for more than $75 \%$ of all waste generated in the province, but manages to divert only $12 \%$ of end of life material from landfills. Using a system based cost model, focus is placed on analyzing

1) What are possible factors that contribute to poor IC\&I diversion performance?

2) What would happen to provincial recycling costs if IC\&I diversion increased?

3) What material types should policy planners prioritize when attempting to increase overall diversion?

The results of this analysis show that Ontario's poor diversion may be explained by low landfill disposal costs and high recycling costs relative to other jurisdictions. While there are significant opportunities to increase diversion in the IC\&I sector, particularly for printed paper and packaging materials, the costs associated with doing so may prove prohibitive to businesses. Significant investments in collection and processing infrastructure may be necessary to accommodate for increases in diverted material from the IC\&I sector. The findings of this study suggest that Ontario prioritize certain materials for increased diversion (due to high levels of recyclability and low cost), and support the sector through revised legislation that addresses who is legally mandated to divert material and who should pay for it.
\end{abstract}

Keywords: Recycling; Industrial, Commercial and Institutional (IC\&I); Cost model; Diversion; Cost containment; Ontario; Canada

\section{Introduction}

Diversion is seen as a potentially significant means to reduce carbon emissions impacts, promote resource stewardship and conservation and encourage a broader movement towards "sustainable living" [1]. However, participation in diversion initiatives in Canada remains low. It is estimated that while more than $75 \%$ of non-hazardous waste can be diverted from landfills, only $30 \%$ of it actually is [2]. Canada as a whole, and Ontario in particular, do a particularly poor job with respect to diversion - the country ranks last in a list of OECD countries with respect to overall waste diversion, while Ontario is among the worst performing provinces in the country (with overall diversion rates of approximately 26\%) [2]. Waste generated from Ontario's Industrial, Commercial and Institutional (IC\&I) sector are diverted at an even lower rate, with only $12 \%$ of total materials generated being measured as diverted [3]. While this seemingly points to deep rooted policy, infrastructural and behavioral impediments to diversion, it also represents a significant opportunity for the province's waste management sector - even incremental improvements in overall diversion levels will have potentially significant impacts on various sustainability metrics (carbon emissions, need to procure virgin materials etc.) Increasing diversion in Ontario's IC\&I sector has been highlighted as policy priority for the province, particularly in light of its poor performance relative to the residential sector. However, there remain a number of obstacles to diversion for the IC\&I sector, the foremost of which remains the costs associated with increasing diversion.

This study examines some of the salient challenges to increasing diversion in Ontario's IC\&I sector, and puts forward potential explanations for the province's poor performance relative to other jurisdictions. To date, Ontario's IC\&I policy and legislative initiatives have struggled to address the scale and scope of IC\&I waste generation. Further compounding the issue is that there is a paucity of reliable data regarding the quantities of waste being generated, recovered, and the costs associated with material management. In light of this, the province has devoted significant resources to better understand the issues facing the IC\&I sector, and it's presently undertaking a legislative review to identify means and methods to increase diversion [4]. However, should increase diversion be emphasized in light of the potentially significant costs associated with the end of life management of IC\&I material?

Using a combination of panel data collected from Ontario's Blue Box, Waste Electronics, Hazardous Waste, Organics and Construction and Demolition programs, this study attempts to quantify the impact of increased diversion in Ontario's IC\&I sector.

To assess the implications of IC\&I diversion, this research examines the following questions:

1) What are possible factors that contribute to poor IC\&I diversion performance?

2) What would happen to provincial recycling costs if IC\&I diversion increased?

3) What material types should policy planners prioritize when attempting to increase overall diversion?

The province is in a unique position to overhaul recycling and

*Corresponding author: Calvin Lakhan, Department of Geography, Wilfrid Laurier University, Waterloo, 21st Madrid Crst, Brampton Ontario, L6S2X, Canada, Tel: (3288)519-884-0710; E-mail: lakh2440@mylaurier.ca

Received October 29, 2015; Accepted December 07, 2015; Published December 13,2015

Citation: Lakhan C (2015) Modeling the Economic Impacts of Increasing Diversion in Ontario's Industrial, Commercial and Institutional (IC\&I) Sector. Adv Recycling Waste Manag 1:101. DOI: 10.4172/2475-7675.1000101

Copyright: ( 2015 Lakhan C. This is an open-access article distributed under the terms of the Creative Commons Attribution License, which permits unrestricted use, distribution, and reproduction in any medium, provided the original author and source are credited. 
diversion for the IC\&I sector. As noted above, there is an opportunity to capture millions of tonnes of potentially valuable material that is presently being disposed of in landfills. However, questions surrounding, who ultimately bares the physical and financial responsibility of this material requires careful consideration.

\section{Literature Review}

There is a relative paucity of literature that specifically examines the challenges of diversion in the IC\&I sector, particularly within a Canadian context. This, in part, is attributed to the lack of formal diversion programs for the IC\&I sector in most jurisdictions - unlike recycling programs for household waste, the management of IC\&I waste is normally left to the discretion of the waste generator. Also, as noted by [5], previous investigations into waste management in the IC\&I sector have shown that it is extremely difficult to obtain data from firms on their waste disposal quantities and costs (1995). Most of the research on IC\&I diversion has generally been grey literature - work carried out by consulting firms or local governments to address site and situation specific issues/conditions related to IC\&I diversion. While there have been previous attempts to estimate the scale of IC\&I waste generation in Ontario [6,7], most of these have omitted discussions surrounding the costs associated with waste management.

Despite the comparative lack of research being conducted on the IC\&I sector as a whole, there exists a number of studies related to waste management in IC\&I sub sectors (automobile manufacturing, restaurants, retailors) and materials (plastics, metals, etc.) [8] Conducted a review of solid waste management in the hospitality industry, attempting to characterize the nature of the waste stream and effective methods for diversion (2014). The authors concluded that while most establishments have strategies to manage waste, the industry would benefit from developing a sustainable waste management program that

a) Maps the flow of waste from the point of generation through final disposition and

\section{b) Focus on reducing the quantities of waste being generated.}

The author's highlighted the latter point as being particular important, as there were significant unrealized opportunities to reduce waste being generated by the hospitality sector. Similar observations (and conclusions) have been made in examinations of the automotive $[9,10]$, office $[11,12]$ and institutional $[13,14]$ sectors. The consensus appears to be that while many IC\&I establishments implement waste management programs, insufficient planning is spent on source reduction, or diverting waste from disposal.

With respect to the recyclability and diversion of individual materials, [15] highlighted the relative immaturity of plastic recycling in the manufacturing sector (1996). The study highlighted that despite the value and overall recyclability of most plastics, many manufacturers lacked waste management programs that emphasized diversion over disposal. Ref. [16,17] have observed similar issues with cardboard/ boxboard recycling - significant quantities of these materials are being disposed of in the waste stream despite their recyclability. Metals recycling appears to be the lone exception when it comes to diverting materials generated by the IC\&I sector - Studies by Ayres, Atherton $[18,19]$ have noted that many manufacturers have closed loop processes to reuse scrap metal, or alternatively, have diversion programs that allow waste generators to sell scrap directly to recycling re-processors.

What has remained conspicuously absent from the aforementioned studies (and recycling research in general) is attempts to quantify the economic impacts of diversion activity. Most of the literature in favor of recycling and diversion cite the benefits of reducing the need to procure material from virgin sources [20]. This has obvious environmental benefits, in that depending on the material being recovered, recycling can reduce emissions output by a factor of $10 x[3,20]$. Furthermore, recycling is seen as promoting resource stewardship and helps preserve declining resource stocks. Increased recycling also reduces the quantities of material being sent to landfills, reducing the strain on landfill capacity and the need to site new landfills (which is becoming increasingly difficult in urban areas). However, the costs associated with developing and operating diversion programs (particularly in the IC\&I sector) can be prohibitive. The consideration of externalities (both economic and environmental) is critical when evaluating the merits of recycling initiatives.

This study attempts to advance the existing discourse on diversion in the IC\&I sector, but shifts the focus away from what is being diverted (or disposed) to how much does it cost. As far as can be ascertained, this is one of the few studies of its kind to evaluate the effectiveness of IC\&I waste management along both environmental and economic lines. By examining the economic viability of IC\&I diversion, policy planners can make informed decisions with respect to how and where to allocate resources to operate the most efficient waste management system possible. This paper aims to address the current gap in the literature by specifically modeling how system costs change in response to changes in diversion. It is important to note that this study does not attempt to offer any definitive guidance regarding the appropriateness of diversion as a sustainability strategy. Instead, it highlights that any proposed increases in diversion must be weighed against budgetary, resource and administrative constraints on both the part of the IC\&I sector and local governments.

\section{Materials and Methods}

\section{Description of study site}

Ontario is Canada's most populous province, situated between $41^{\circ} 85^{\prime} \mathrm{N}$ and $51^{\circ} 28^{\prime} \mathrm{N}$ and $95^{\circ} 48^{\prime} \mathrm{W}$ and $74^{\circ} 74^{\prime} \mathrm{W}$, with a total land mass of $1,076,395 \mathrm{~km}^{2}$. Ontario remains at the forefront of recycling initiatives and legislation, recognized as one of only three provinces in Canada to implement an extended producer responsibility scheme (EPR) for household recyclables. Residential and commercial waste diversion programs exist for MHSW (Material Hazardous or Special Waste) [21], WEEE (Waste Electrical and Electronics Equipment), automobile tires, and printed paper and packaging (Blue Box) materials. Each of these programs exists under the oversight of Waste Diversion Ontario, (WDO), and a non-crown corporation created under Ontario's 2002 Waste Diversion Act [3]. The Waste Diversion Act (WDA) establishes waste diversion programs through arm's length, not-for-profit organizations. Waste Diversion Ontario oversees program development and implementation, while the industry-funding organizations (Stewardship Ontario; Ontario Tire Stewardship; Ontario Electronic Stewardship) [22] report to WDO on targets achieved, operate the programs, and levy fees on producers to cover program costs. The Minister of the Environment $[23,24]$ may issue policy direction to WDO and is responsible for enforcement, but does not otherwise have a direct relationship with the IFOs under the WDA (Waste Diversion Ontario, 2012).

Ontario's waste is regulated through a combination of mandatory and voluntary recycling initiatives. Tables 1 and 2 describe both the mandatory and voluntary diversion initiatives operating for the full 
Citation: Lakhan C (2015) Modeling the Economic Impacts of Increasing Diversion in Ontario's Industrial, Commercial and Institutional (IC\&I) Sector. Adv Recycling Waste Manag 1:101. DOI: 10.4172/2475-7675.1000101

Page 3 of 10

range of residential and IC\&I materials generated in the province.

What is interesting to note is the apparent disconnect between the range of materials covered by recycling programs and diversion performance. While either voluntary or mandatory recycling programs exist for the full range of materials found in Ontario's waste stream, overall diversion remains quite low. It should be noted that the recycling performance of mandatory programs is materially higher than voluntary initiatives - an expected result, as most fail to keep track of overall generation and diversion rates.

\section{Data sources}

Data for Ontario's IC\&I sector was obtained from annual reports published by Stewardship Ontario, [22], Ontario Tired Stewardship, Waste Diversion Ontario, Statistics Canada and sector specific industry organizations. Table 3 summarizes the materials included in this study:

\section{Description of Ontario's IC\&I sector}

Ontario's IC\&I sector includes industrial, commercial and institutional facilities who generate waste in the province. IC\&I waste is traditionally defined as waste managed off site at disposal, recycling, energy from waste or compositing sites. This definition excludes waste managed on site, and waste materials that is used as a feedstock for other processes by the generator. This definition traditionally excludes agricultural, mining and nuclear waste. Waste associated with primary resource extraction and liquid hazardous waste is also generally not considered IC\&I waste. Table 4 summarizes IC\&I industry groups covered under Ontario's waste legislation. Broadly speaking, waste generated by the IC\&I sector can be divided into two primary streams:
1) Hazardous and

2) Non Hazardous waste.

We define these terms as:

Hazardous waste: A solid waste or combination of solid waste, which because of its quantity, concentration, or physical, chemical, or infectious characteristics may

(a) cause, or significantly contribute to, an increase in mortality or an increase in serious, irreversible, or incapacitating reversible, illness; or

(b) Pose a substantial presenter potential hazard to human health or the environment when improperly treated, stored, transported, or disposed of, or otherwise managed. (RCRA 1004(5))"

Non hazardous waste: "Non-hazardous waste is defined by the Environmental protection Act (EPA) through Regulation 347 - General Waste management. Regulation 347 defines curbside household garbage and similar waste generated by businesses and institutions as solid non-hazardous waste - this definition also includes construction and demolition wastes such as drywall and roofing materials. (Ontario Environmental Protection Act, RRO: 1990, Reg. 347)

Approximately $89 \%$ of all materials generated in Ontario is comprised of Non Hazardous waste, of which, 6.8 million tonnes is generated by industrial, commercial and institutional establishments [3]. The IC\&I sector in Ontario is responsible for more than $70 \%$ of all material generated in the province [3], but manages to divert only a small percentage of their overall waste. In theory, all of these materials can be diverted under existing provincial waste management programs. However, overall diversion for the province remains alarmingly low

\begin{tabular}{|c|c|c|c|c|c|}
\hline Program Name & Wastes Managed & Tonnes Managed $^{1}$ & $\begin{array}{c}\text { Diversion/ } \\
\text { Collection rate }\end{array}$ & $\begin{array}{l}\text { Waste generated as approx. \% } \\
\text { of total ON generation }{ }^{3}\end{array}$ & Source of waste \\
\hline Blue Box & $\begin{array}{c}\text { Packaging comprised of: } \\
\text { - } \quad \text { Glass } \\
\text { - } \quad \text { Papetal } \\
\text { - } \quad \text { Plastics } \\
\\
\text { Printed paper (e.g., newsprint, } \\
\text { magazines) }\end{array}$ & 892,924 diverted (2012) & $63 \%$ & $12 \%$ & Residential \\
\hline $\begin{array}{l}\text { Municipal Hazardous } \\
\text { or Special Waste } \\
\text { Public name: "Orange } \\
\text { Drop" }\end{array}$ & $\begin{array}{ll}\text { Nine types of waste, including: } \\
\text { - } & \text { Paints and solvents } \\
\text { - } & \text { Antifle-use batteries } \\
\text { - } & \text { Fertilizers } \\
\text { - } & \text { Pesticides } \\
\text { - } & \text { ompty oil containers and } \\
\text { - } & \text { Propane tanks and other } \\
& \text { pressurized containers }\end{array}$ & 28,280 collected $(2013)$ & $66 \%$ & $0.4 \%$ & $\begin{array}{l}\text { Residential/small } \\
\text { quantity IC\&I }\end{array}$ \\
\hline Used Tires & $\begin{array}{l}\text { Tires (e.g., passenger tires, off-the-road } \\
\text { tires) }\end{array}$ & 170,184 diverted (2013) & $100 \%$ & $1.3 \%$ & Residential/IC\&I \\
\hline $\begin{array}{l}\text { Waste Electrical and } \\
\text { Electronic Equipment }\end{array}$ & $\begin{array}{c}\text { Forty-four wastes, including: } \\
\text { - } \quad \text { TVs and monitors } \\
\text { - } \quad \text { Mice and other peripherals } \\
\text { - } \quad \text { CDs, DVDs, and players } \\
\text { - } \\
\text { - } \text { Phones } \\
\text { - Radios , photocopiers } \\
\text { Audio-visual equipment }\end{array}$ & 76,764 collected $(2013)$ & $63 \%$ & $1.1 \%$ & Residential/IC\&I \\
\hline
\end{tabular}

(Footnotes)

${ }^{1} \mathrm{MHSW}$ and WEEE programs use "collection" rather than "diversion" to measure performance, as these programs are intended to recycle or safely dispose of wastes. ${ }^{2}$ Diversion/collection rate is listed as a percentage of tonnes available for diversion/collection.

${ }^{3}$ This column shows the total wastes available for diversion/collection in each program, as a percentage of total non-hazardous waste generated in Ontario. Table 1: Mandatory Recycling Programs in Ontario. 
Citation: Lakhan C (2015) Modeling the Economic Impacts of Increasing Diversion in Ontario's Industrial, Commercial and Institutional (IC\&I) Sector. Adv Recycling Waste Manag 1:101. DOI: 10.4172/2475-7675.1000101

Page 4 of 10

\begin{tabular}{|c|c|c|c|}
\hline Program Name & Wastes Managed & Tonnes Managed $^{1}$ & Source of waste \\
\hline Ontario Medications Return & Pharmaceuticals & 331 tonnes collected (2013) & Residential \\
\hline Ontario Sharps Collection & Sharps & 212 tonnes collected $(2013)$ & Residential \\
\hline $\begin{array}{l}\text { Ontario Deposit Return } \\
\text { Public name: } \\
\text { "Bag it Back" }\end{array}$ & $\begin{array}{l}\text { Alcohol beverage containers (plastic, } \\
\text { metal, glass, or any combination) and } \\
\text { packaging }\end{array}$ & $\begin{array}{c}302 \text { million containers collected ( } 80 \% \text { collection } \\
\text { rate); over } 112,000 \text { tonnes of packaging } \\
\text { diverted } \\
(2012 / 13)\end{array}$ & Residential/IC\&I \\
\hline The Beer Store Bottle Return² & $\begin{array}{l}\text { Beer containers (metal, glass, plastic) and } \\
\text { packaging }\end{array}$ & $\begin{array}{l}2 \text { billion containers collected (92\% collection } \\
\text { rate); over } 333,000 \text { tonnes of packaging } \\
\text { diverted }(2012 / 13)\end{array}$ & Residential/IC\&I \\
\hline Return to Retail & $\begin{array}{l}\text { Mercury-containing fluorescent lamps } \\
\text { and bulbs }\end{array}$ & N/A & Residential \\
\hline Take Back the Light & $\begin{array}{l}\text { Mercury-containing fluorescent lamps } \\
\text { and bulbs }\end{array}$ & $\begin{array}{c}1,961 \text { tonnes collected } \\
(2008-2013)\end{array}$ & IC\&I \\
\hline Switch the 'Stat & Mercury-containing thermostats & $\begin{array}{l}25,000 \text { units collected } \\
(2006-2010)\end{array}$ & Residential/IC\&I \\
\hline Recycle My Cell & Cell phones and accessories & $\begin{array}{c}\text { Over 580,000 units collected } \\
(2005-2012)\end{array}$ & Residential/IC\&I \\
\hline Call2Recycle $^{3}$ & $\begin{array}{c}\text { Rechargeable batteries, cellphone } \\
\text { batteries }\end{array}$ & $\begin{array}{c}100 \text { tonnes collected per year (on average, } \\
\text { between } 1997 \text { and 2013) }\end{array}$ & Residential/IC\&I \\
\hline $\begin{array}{l}\text { Selected Household Hazardous Waste } \\
\text { Initiative } \\
\text { Public name: "Phase2" }\end{array}$ & $\begin{array}{c}\text { Wastes formerly included in MHSW: } \\
\text { - } \quad \text { Rechargeable batteries } \\
\text { - } \quad \text { Pluortable fire extinguishers } \\
\text { - } \quad \text { Mercury-containt bulbs and } \\
\text { - } \quad \text { Pharmaceuticals and Sharps }\end{array}$ & $\begin{array}{l}388 \text { tonnes collected } \\
\text { (estimated annual collection based on 2012- } \\
2013 \text { data) }\end{array}$ & Residential/small quantity IC\&I \\
\hline
\end{tabular}

(Footnotes)

'Where programs use "collection" rather than "diversion" to measure performance, these programs' objectives are often to recycle and safely dispose of wastes. 'Brewers' Retail Inc. is exempted by the WDA from Blue Box requirements for packaging associated with beer but is required to report to WDO on the operation of its Bottle Return system. The WDA grants the Minister the regulatory power to lift this exemption and subject Brewers' Retail Inc. to Blue Box producer requirements. ${ }^{3}$ Call2Recycle Canada has submitted for WDO's consideration an Industry Stewardship Plan to manage single-use (non-rechargeable) batteries. Call2Recycle Canada indicated its intent to continue to manage rechargeable batteries in Ontario. Table 2: Voluntary Recycling Programs in Ontario.

\begin{tabular}{|c|c|}
\hline \multicolumn{2}{|c|}{ Materials } \\
\hline Newsprint & $\begin{array}{c}\text { Printing, Copying \& Multi-Function } \\
\text { Devices }\end{array}$ \\
\hline Paper & Anti-Freeze \\
\hline Corrugated Cardboard/Boxboard & Oil Containers \\
\hline PET Bottles & Oil Filters \\
\hline HDPE Bottles & Paints and Coatings \\
\hline Other Plastics & Pressurized Containers \\
\hline Non Ferrous Metals & Single Use Dry Cell Batteries \\
\hline Ferrous Metals & Construction and Demolition Materials \\
\hline Glass & Scrap Metal \\
\hline Desktop Computers & Wood \\
\hline Display Devices & Yard Waste \\
\hline Portable Computers & Food \\
\hline
\end{tabular}

Table 3: List of IC\&I Materials.

- While Ontario's recycling rate for residential printed paper and packaging (Blue Box) is the highest in Canada, the diversion level for the IC\&I sector is less than $12 \%$. As a result, diversion rates for the province as a whole lags behind other jurisdictions (As shown in Figure $1)$.

This is a seemingly unexpected result - Ontario has had a recycling system in place for more than 30 years, and has regulations legislatively requiring both households and IC\&I establishments to recycle. However, the scope of waste generation, both with respect to the sources of waste and what is actually covered by existing regulations helps shed some light on the issue.

Existing provincial regulations apply exclusively to large IC\&I waste generators (see description below), it is estimated that most of the waste generated by the IC\&I sector comes from small and medium size establishments, and thus, fall outside the purview of existing regulations [25]. According to Industry Canada, only $19 \%$ of all employees in the province work in large IC\&I establishments (where large is defined as an establishment with more than 500 employees) [6]. Thus, in order to divert (or at the very least, regulate) the material being generated by the IC\&I sector, the $3 \mathrm{R}$ regulations will have to be amended to increase the threshold to include medium and small businesses.

However, there are a number of unique challenges for establishing and implementing waste division programs in the IC\&I sectors:

- Diverse types and volumes of wastes generated between sectors.

- Sectors do not report the types and volumes of waste managed and diverted.

- $\quad$ The wide variety of individual establishments, which range from small family businesses to large, global companies.

- The economics if managing IC\&I waste

The last point - the economics of managing IC\&I waste, is largely the focus of this study. Section 4 examines possible reasons for low IC\&I sector diversion, and as an extension, examines the economic impacts of attempting to increase IC\&I diversion.

\section{Cost modeling}

Description of model: To quantify the full economic and diversion impacts of IC\&I sector diversion, a cost model was developed to achieve the following

a) Calculate the incremental cost of diverting additional IC\&I 
Diversion Rate \% across provinces

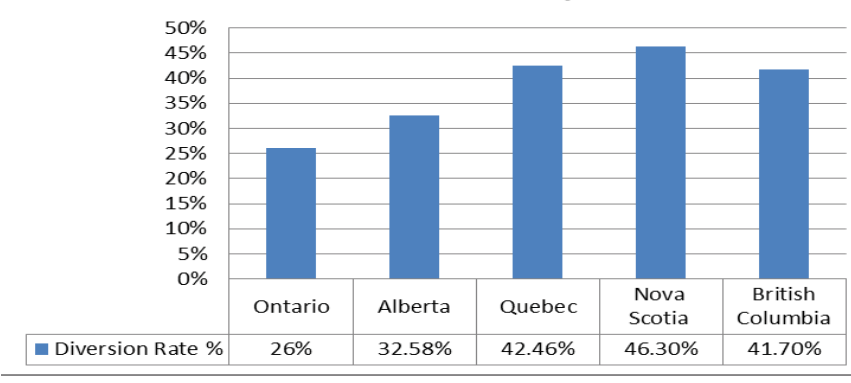

Figure 1: Overall Diversion Rates Across Canadian Jurisdictions.

material,

b) model a scenario that achieved Ontario's $10 \%$ diversion goal using the "next least cost tonne" approach c) estimate the costs of adding incremental capacity to the recycling system and

d) identify what materials (if any) should be targeted for recovery.

The cost model developed for this study used data collected from data reported from Stewardship Ontario, Ontario Electronic Stewardship, Waste Diversion Ontario, and annual reports from the construction and demolition and food waste sectors. The model was developed in Microsoft Excel and allows users to do the following:

- Alter the number of tonnes recovered for individual material types to re-calculate impact of increased IC\&I diversion on system costs and diversion rates.

- $\quad$ Set a goal recycling rate (currently set at $22 \%$ ). The model then calculates the impact on ICI system costs and material recovery rates of achieving the goal recycling rate at the lowest possible cost (using the next least cost tonne approach). The model output is total system costs and material specific recycling rates.

- Calculate the additional infrastructural costs (if any) for adding additional recyclable material to the existing recycling system.

\section{Model limitations/applicability}

Limitations: Unlike residential recycling programs, there is relative paucity of data for the IC\&I sector. Waste generators are under no obligation to report the total quantities of waste generated or diverted to a common oversight body, which makes calculating diversion levels difficult. The Statistics Canada Waste Management Industry survey does however report total quantities of material diverted in the province for sub material types, but does not make a distinction between whether this material comes from the residential or IC\&I sector.

Readily quantifying the costs of diverting/disposing of IC\&I material also remains a challenge, as individual generators do not disclose this information publicly (in many instances, collection services for waste generators are carried out by private service providers, and as such, individual contract information may be sensitive). To help overcome this issue, data from Ontario's residential recycling programs are used as proxies for material management costs in the IC\&I sector, and also used to "back calculate" IC\&I diversion using the Statistics Canada WIMIS survey.

With respect to the costs of diversion and disposal, 22 of the 27 materials currently obligated under IC\&I regulations are also regulated under other provincial residential diversion programs. Given that material management costs are readily available for the residential waste and recovery stream, this study uses them as substitutes for IC\&I materials. Data for C\&D and organic waste was obtained from secondary sources (annual/industry reports) from stakeholders in these sectors. Whether this approach is appropriate remains an issue open for debate - there is no precedent in the literature to use this approach for quantifying IC\&I costs. However, when examining how waste material flows through a system, the differences between the IC\&I and residential sector are largely confined to methods of collection. IC\&I collection is likely to have lower costs collecting an equivalent tonne of material, as there are fewer stops to make, and larger concentrations of material per stop. However, this material is then sent to a material recycling facility (or waste electronics/hazardous waste depot) that manages both residential and IC\&I waste (often managing material for both streams simultaneously). Processing costs and realized revenue from sale of sorted recyclables is unlikely to vary between residential and IC\&I sources. To account for potential differences in collection costs, residential figures for material collection costs have been reduced by $20 \%$. Users have the ability to change this value in the model should they be privy to better information, or would like to test alternative collection scenarios.

In order to calculate levels of IC\&I generation and diversion by material type, residential tonnages were subtracted from the aggregated generation/diversion figures provided by the Statistics Canada WIMIS survey. The net result is material generated from industrial and commercial sources. It should be noted that while attempts have been made in the past to ascertain the total quantities of IC\&I sector waste generation and recovery in the past (for specific sub sectors, i.e., restaurants, or cities), few studies has examined the impacts for the province as a whole.

Table 5 below reports the estimated recycling rates, tonnes generated/diverted and the net cost per tonne for end of life material management for the materials used in this study.

Applicability: While this model provides useful insights into the costs of managing material generated from the ICI sector, its applicability to other jurisdictions is somewhat questionable. The costs of recycling are a function of a number of local characteristics and conditions (access to MRF, type of MRF, local labor market, realized commodity prices, maturity of recycling system etc.) that make it difficult to quantify the effects of changes to the recycling system using a generic "one size fits all" approach. With that being said, that was never the intended purpose or function of the model - it was designed with two purposes in mind:

1) To quantify the economic and diversion impact of increasing diversion in the ICI sector, and

2) To force policy planners to think about, "What is the opportunity cost of incremental diversion?

Recycling is largely seen as a net social and environmental good. Generally speaking, there is an opinion among stakeholders that "more is better" in conversations surrounding recycling. However, at what point does increased diversion become undesirable? In Lakhan's study examining the optimal mix of Blue Box materials, it was found that the province could recover $60 \%$ of household recyclables, at a cost of $\$ 157$ million dollars (by focusing on core materials - where core materials are defined as newsprint, cardboard, boxboard, aluminum, steel, PET/HDPE plastics and glass) (2015). To get to a $62 \%$ recycling rate, overall system costs increased by almost $\$ 50$ million dollars. For every additional tonne recycled, system costs increased by more than $\$ 2400$ 
Citation: Lakhan C (2015) Modeling the Economic Impacts of Increasing Diversion in Ontario's Industrial, Commercial and Institutional (IC\&I) Sector. Adv Recycling Waste Manag 1:101. DOI: 10.4172/2475-7675.1000101

Page 6 of 10

\begin{tabular}{|c|c|}
\hline \multicolumn{2}{|c|}{ Sector } \\
\hline Agriculture, forestry, fishing, hunting & Education Services \\
\hline Mining, oil, gas extraction and utilities & Health Care and Social Assistance \\
\hline Manufacturing & Arts, Entertainment and Recreation \\
\hline Wholesale Trade & Accommodation and food services \\
\hline Retail Trade & Other services \\
\hline Transportation and warehousing & Public Administration \\
\hline Finance, Insurance, Real Estate, renting and leasing & Professional, scientific, and technical services \\
\hline Admin and Support, Waste Management and Remediation Services & Information and Cultural Industries \\
\hline
\end{tabular}

Table 4: List of Obligated IC\&I Sectors.

\begin{tabular}{|c|c|c|c|c|}
\hline \multirow[t]{2}{*}{ Material } & \multicolumn{3}{|c|}{ Tonnage Data } & \multirow{2}{*}{$\begin{array}{c}\text { Net System Costs } \\
\text { (\$/tonnes) }\end{array}$} \\
\hline & Generation (Sheet 1) & Recovery (Sheet 1) & $\mathbf{R R} \%$ & \\
\hline Newsprint & $290,000 \mathrm{~T}$ & $182,000 \mathrm{~T}$ & $63 \%$ & $\$ 55.37$ \\
\hline Paper & $1,655,000 \mathrm{~T}$ & $302,000 \mathrm{~T}$ & $18 \%$ & $\$ 91.66$ \\
\hline Corrugated Cardboard/Boxboard & $990,000 \mathrm{~T}$ & $275,000 \mathrm{~T}$ & $28 \%$ & $\$ 179.40$ \\
\hline \multicolumn{5}{|l|}{ Fiber } \\
\hline PET Bottles & $15,000 \mathrm{~T}$ & $2,050 \mathrm{~T}$ & $14 \%$ & $\$ 756.48$ \\
\hline HDPE Bottles & $120,000 \mathrm{~T}$ & $1,640 \mathrm{~T}$ & $1 \%$ & $\$ 623.75$ \\
\hline Other Plastics & $535,000 \mathrm{~T}$ & $7,311 \mathrm{~T}$ & $1 \%$ & $\$ 1,343.84$ \\
\hline \multicolumn{5}{|l|}{ Plastics } \\
\hline Non Ferrous & $300,000 \mathrm{~T}$ & $58,000 \mathrm{~T}$ & $19 \%$ & $\$(384.82)$ \\
\hline Ferrous & $470,000 \mathrm{~T}$ & $188,000 \mathrm{~T}$ & $40 \%$ & $\$(9.57)$ \\
\hline \multicolumn{5}{|l|}{ Metals } \\
\hline Glass & $275,000 \mathrm{~T}$ & $71,000 \mathrm{~T}$ & $26 \%$ & $\$ 51.68$ \\
\hline \multicolumn{5}{|l|}{ Glass } \\
\hline Printed Paper and Packaging & $4,650,000 \mathrm{~T}$ & $1,087,000 \mathrm{~T}$ & & \\
\hline Wood & $505,000 \mathrm{~T}$ & $51,996 \mathrm{~T}$ & $10 \%$ & $\$ 141.28$ \\
\hline Yard Waste & $105,000 \mathrm{~T}$ & $10,811 \mathrm{~T}$ & $10 \%$ & $\$ 145.19$ \\
\hline Food & $740,000 \mathrm{~T}$ & $76,193 \mathrm{~T}$ & $10 \%$ & $\$ 223.94$ \\
\hline Organics & $1,350,000 \mathrm{~T}$ & $139,000 \mathrm{~T}$ & & \\
\hline Display Devices & $54,064 \mathrm{~T}$ & $38,943 \mathrm{~T}$ & $72 \%$ & $\$ 986.94$ \\
\hline Desktop Computers & $4,713 \mathrm{~T}$ & $2,103 \mathrm{~T}$ & $45 \%$ & $\$ 3,200.63$ \\
\hline Portable Computers & $9,071 \mathrm{~T}$ & $6,152 \mathrm{~T}$ & $68 \%$ & $\$ 196.60$ \\
\hline Printing, Copying \& Multi-Function Devices & $101,262 \mathrm{~T}$ & $26,372 \mathrm{~T}$ & $26 \%$ & $\$ 287.95$ \\
\hline Waste Electronics & $169,110 \mathrm{~T}$ & $73,570 \mathrm{~T}$ & & \\
\hline Anti-Freeze & $7,968 \mathrm{~T}$ & $3,187 \mathrm{~T}$ & $40 \%$ & $\$ 698.03$ \\
\hline Oil Containers & $2,512 \mathrm{~T}$ & $1,055 \mathrm{~T}$ & $42 \%$ & $\$ 2,976.62$ \\
\hline Oil Filters & $14,249 \mathrm{~T}$ & $10,687 \mathrm{~T}$ & $75 \%$ & $\$ 1,051.72$ \\
\hline Paints and Coatings & $22,422 \mathrm{~T}$ & $8,296 \mathrm{~T}$ & $37 \%$ & $\$ 2,825.79$ \\
\hline Pressurized Containers (Non refillable) & $2,512 \mathrm{~T}$ & $628 \mathrm{~T}$ & $25 \%$ & $\$ 1,052.39$ \\
\hline Pressurized Containers (Refillable) & $112 \mathrm{~T}$ & $104 \mathrm{~T}$ & $93 \%$ & $\$ 2,835.58$ \\
\hline Single Use Dry Cell Batteries & $7,642 \mathrm{~T}$ & $1,452 \mathrm{~T}$ & $19 \%$ & $\$ 1,935.33$ \\
\hline Solvents & $83,520 \mathrm{~T}$ & $4,176 \mathrm{~T}$ & $5 \%$ & $\$ 158.05$ \\
\hline Hazardous Waste & $140,936 \mathrm{~T}$ & $29,585 \mathrm{~T}$ & & \\
\hline Construction and Demolition & $631,004 \mathrm{~T}$ & $157,751 \mathrm{~T}$ & $25 \%$ & $\$ 224.44$ \\
\hline
\end{tabular}

Table 5: Material specific tonnage and cost information.

[26]. The above example highlights a situation where the marginal cost of diversion is significant, necessitating that we ask the question: Is the decision to recycling everything, everywhere, the right choice?

\section{Results and Discussion}

\section{Economics of recycling in Ontario}

The economics of recycling for IC\&I establishments is a topic that has received scant attention from researchers and policy planners. Ontario has unique characteristics with respect to the economics of waste management relative to other jurisdictions. Table 6 below summarizes interprovincial costs of recycling for five Canadian provinces (with inter-provincial costs compiled using the Statistics
Canada WIMIS survey). We note that provinces differ significantly in the costs to both dispose and recycle material. The most salient examples include differences in tipping fees, cost of operating transfer stations and recycling facilities and the cost of shipping material to US Landfills. Figures 2-5 graph the interprovincial costs for certain disposal activities (tipping fees and cost to ship material to US landfills).

The following inferences can be drawn from the above graphs:

- $\quad$ Provinces with the lowest cost to dispose material (expressed as either provincial tipping fee or cost to ship material to US landfills) divert the least amount of material [22].

- Provinces with the lowest diversion rates also, on average, 


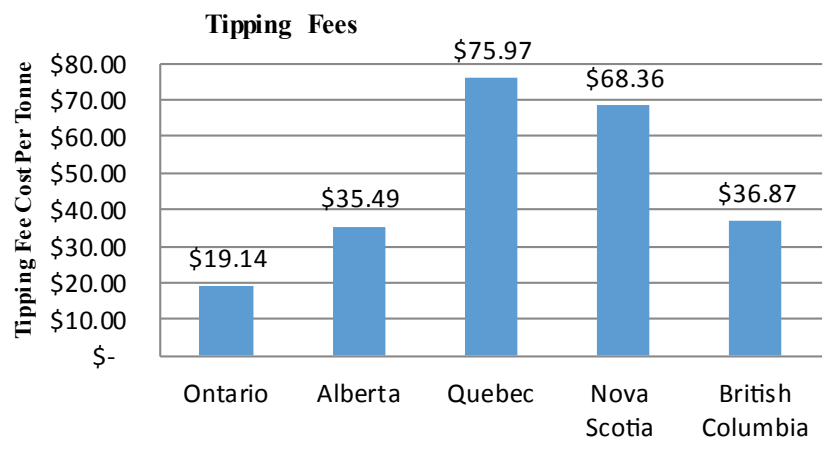

Figure 2: Tipping Fees.

\section{Operation of Recycling Facilities}

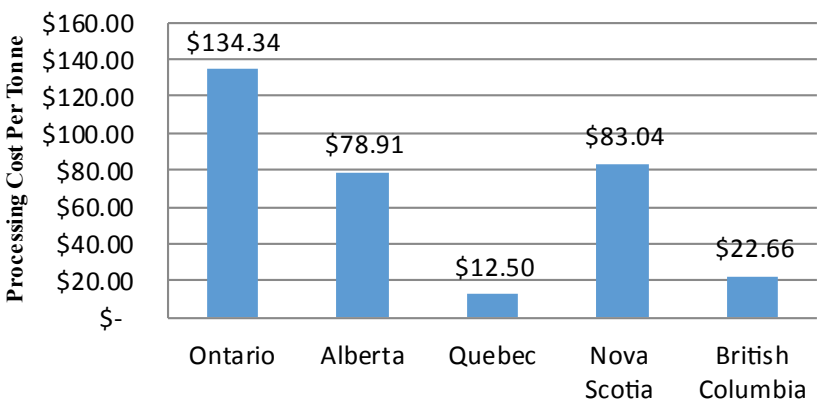

Figure 3: Operation of Recycling Facilities.

Operation of Transfer Stations
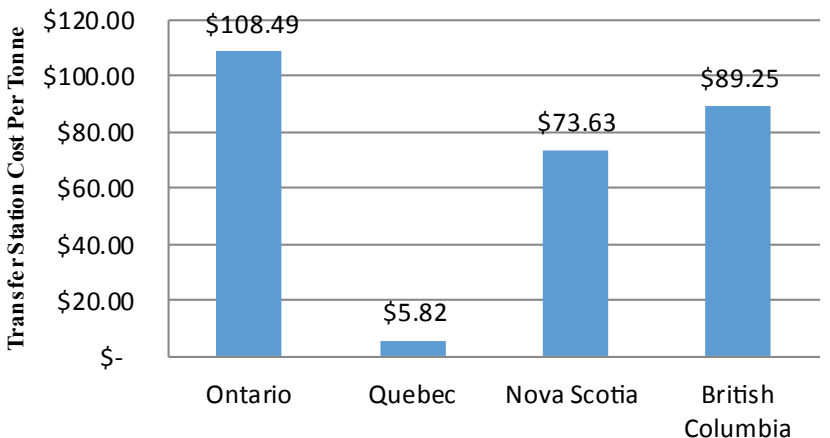

Figure 4: Operation of Transfer Stations.

Cost Per Tonne for Transport to Nearest U.S Landfill

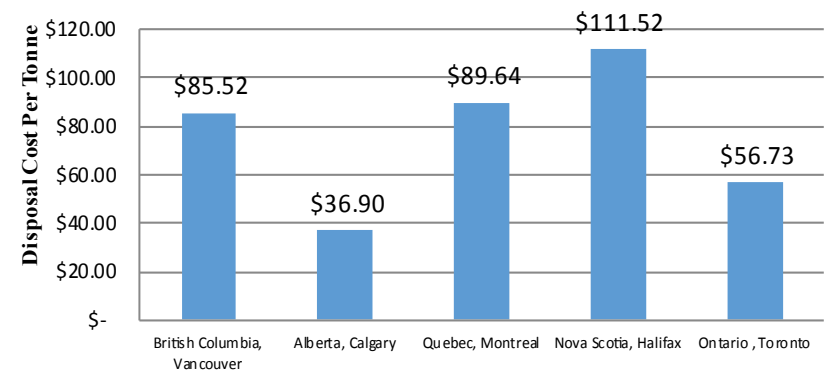

Figure 5: Cost per Tonne for Transport to Nearest U.S Landfill. face higher costs of recycling. Provinces with the highest levels of diversion face both

A) The highest cost of disposal and

b) The lowest cost to recycle

One pay posit that the reason for differences in diversion across provinces may simply be economic in nature - it's not necessarily that other provinces are performing "better" than Ontario, but rather, they do not enjoy the same cost advantages when it comes to disposal. The net result of these unique challenges is that IC\&I waste generators, rather than product manufactures, tend to pay directly for the cost associated with waste diversion. While limited data is available to provide a clear picture of the types and volumes of materials that each IC\&I sector produces, section 4.2 below examines the economic implications of increasing diversion in the IC\&I sector in Ontario.

\section{Modeling the costs of increased diversion in the IC\&I Sector}

Using the cost model described in section 3.4, a scenario was modeled that increases the provincial IC\&I diversion rate from a baseline scenario ( $12 \%$ diversion) to a goal scenario of $22 \%$. This represents a $10 \%$ in overall sector diversion. Using Excel's solver feature, increases in overall sector diversion adhered to the principle of the "next least cost tonne", where increases in diversion were achieved at the lowest possible cost. A limit was placed on the maximum recycling rate that could be achieved for individual material types (the maximum values could not exceed $25 \%$ above the historical recycling rate average). This was done to approximate for what could possibly be achieved given current recycling behavior, technology and end markets - for example, while box board is a low cost, easy to recycle material, it is unlikely that it will achieve a 100\% recycling rate. Figure 6 below summarizes the model output. Table 7 summarizes how the recovery of individual material types has changed under our modeled scenario. Based on the modeling results above, a $10 \%$ increase in overall diversion would increase net system costs by approximately $\$ 65$ million dollars. It should be noted that the situation modeled represents a "best case" scenario - the model is designed to specifically prioritize low cost materials for diversion. The incremental cost for every additional tonne diverted in the modeled scenario is $\$ 167.62 /$ tonne (compared to average costs of approximately $\$ 300 /$ tonne for the IC\&I sector as a whole). Even under this largely unrealistic hypothetical, the cost of reaching a $22 \%$ diversion rate is still quite significant. Given that the province has previously signaled their intention to work towards a $60 \%$ diversion rate for the IC\&I sector, the costs of doing so could total in the billions of dollars - costs that are presently born exclusively by waste generators and local government.

\section{Modeling the costs of increased capacity}

Given that additional tonnes are being added to the recycling system under the modeled scenario (described in section 4.2), a provision was built into the model to estimate the costs of building additional capacity within the recycling. Much like landfill capacity, capacity within the recycling system is finite. Material recycling facilities, transfer stations, depots and incineration cites have a limit on the amount of material they can manage in a given period. Thus, any increases in diversion, in addition to calculating the costs of managing material, must be weighed against the infrastructural costs of adding additional system capacity. While estimates for how much capacity remains in the existing system are inexact (estimates range from 1.5 to 1.8 million tonnes), there appears to be a consensus that the current system lacks the ability to readily add incremental capacity. 
Citation: Lakhan C (2015) Modeling the Economic Impacts of Increasing Diversion in Ontario's Industrial, Commercial and Institutional (IC\&I) Sector. Adv Recycling Waste Manag 1:101. DOI: 10.4172/2475-7675.1000101

Page 8 of 10

\begin{tabular}{|c|c|c|c|c|c|}
\hline Activity Type & Ontario & Alberta & Quebec & Nova Scotia & British Columbia \\
\hline $\begin{array}{l}\text { Total Tonnes } \\
\text { (Disposed) }\end{array}$ & $5,083,500 \mathrm{~T}$ & $2,297,149 \mathrm{~T}$ & $2,107,422 \mathrm{~T}$ & $165,524 \mathrm{~T}$ & $1,256,163 \mathrm{~T}$ \\
\hline $\begin{array}{l}\text { Total Tonnes } \\
\text { (Diverted) }\end{array}$ & $598,268 \mathrm{~T}$ & $330,585 \mathrm{~T}$ & $1,012,706 \mathrm{~T}$ & $94,337 \mathrm{~T}$ & $582,942 \mathrm{~T}$ \\
\hline Diversion Rate \% & $11 \%$ & $12.58 \%$ & $32.46 \%$ & $36.30 \%$ & $31.70 \%$ \\
\hline Transportation & $\$ 83.29$ & $\$ 58.41$ & $\$ 111.97$ & $\$ 114.84$ & $\$ 75.81$ \\
\hline Tipping Fees & $\$ 19.14$ & $\$ 35.49$ & $\$ 75.97$ & $\$ 68.36$ & $\$ 36.87$ \\
\hline $\begin{array}{c}\text { Operation of Disposal } \\
\text { Facilities }\end{array}$ & $\$ 33.63$ & $\$ 23.53$ & $\$ 38.10$ & $\$ 178.78$ & $\$ 100.49$ \\
\hline $\begin{array}{c}\text { Operation of Transfer } \\
\text { Stations }\end{array}$ & $\$ 108.49$ & $\$-$ & $\$ 5.82$ & $\$ 73.63$ & $\$ 89.25$ \\
\hline $\begin{array}{c}\text { Operation of } \\
\text { Recycling Facilities }\end{array}$ & $\$ 134.34$ & $\$ 78.91$ & $\$ 12.50$ & $\$ 83.04$ & $\$ 22.66$ \\
\hline Other Expenditures & $\$ 21.89$ & $\$ 12.61$ & $\$ 16.47$ & $\$ 37.43$ & $\$ 21.37$ \\
\hline $\begin{array}{l}\text { Cost of Shipping } \\
\text { Material to United } \\
\text { States }^{*}\end{array}$ & $\$ 56.73$ & $\$ 36.90$ & $\$ 89.64$ & $\$ 111.52$ & $\$ 85.52$ \\
\hline
\end{tabular}

Table 6: Interprovincial comparison of disposal and recycling costs.

\begin{tabular}{|c|c|c|c|}
\hline \multirow{2}{*}{ Material } & \multicolumn{3}{|c|}{ Tonnage Data } \\
\hline & Baseline & Modeled & Difference \\
\hline Newsprint & $182,000 \mathrm{~T}$ & $264,219 \mathrm{~T}$ & $82,219 \mathrm{~T}$ \\
\hline Paper & $302,000 \mathrm{~T}$ & $530,314 \mathrm{~T}$ & $228,314 \mathrm{~T}$ \\
\hline $\begin{array}{l}\text { Corrugated Cardboard/ } \\
\text { Boxboard }\end{array}$ & $275,000 \mathrm{~T}$ & $464,314 \mathrm{~T}$ & $189,314 \mathrm{~T}$ \\
\hline Fiber & & $\mathbf{T}$ & \\
\hline PET Bottles & $2,050 \mathrm{~T}$ & $2,760 \mathrm{~T}$ & $711 \mathrm{~T}$ \\
\hline HDPE Bottles & $1,640 \mathrm{~T}$ & $1,646 \mathrm{~T}$ & $7 \mathrm{~T}$ \\
\hline Other Plastics & $7,311 \mathrm{~T}$ & $7,444 \mathrm{~T}$ & $134 \mathrm{~T}$ \\
\hline Plastics & & $\mathbf{T}$ & $\mathbf{T}$ \\
\hline Non Ferrous & $58,000 \mathrm{~T}$ & $70,421 \mathrm{~T}$ & $12,421 \mathrm{~T}$ \\
\hline Ferrous & $188,000 \mathrm{~T}$ & $272,478 \mathrm{~T}$ & $84,478 \mathrm{~T}$ \\
\hline Metals & & $\mathbf{T}$ & $\mathbf{T}$ \\
\hline Glass & $71,000 \mathrm{~T}$ & $83,619 \mathrm{~T}$ & $12,619 \mathrm{~T}$ \\
\hline Glass & & & $\mathbf{T}$ \\
\hline $\begin{array}{l}\text { Printed Paper and } \\
\text { Packaging }\end{array}$ & $1,087,000 \mathrm{~T}$ & $1,087,000 \mathrm{~T}$ & $\mathbf{T}$ \\
\hline Wood & $51,996 \mathrm{~T}$ & $58,764 \mathrm{~T}$ & $6,768 \mathrm{~T}$ \\
\hline Yard Waste & $10,811 \mathrm{~T}$ & $11,104 \mathrm{~T}$ & $293 \mathrm{~T}$ \\
\hline Food & $76,193 \mathrm{~T}$ & $90,725 \mathrm{~T}$ & $14,533 \mathrm{~T}$ \\
\hline Organics & $139,000 \mathrm{~T}$ & $139,000 \mathrm{~T}$ & $\mathbf{T}$ \\
\hline Display Devices & $38,943 \mathrm{~T}$ & $38,943 \mathrm{~T}$ & $\mathrm{~T}$ \\
\hline Desktop Computers & $2,103 \mathrm{~T}$ & $2,103 \mathrm{~T}$ & $\mathrm{~T}$ \\
\hline Portable Computers & $6,152 \mathrm{~T}$ & $6,152 \mathrm{~T}$ & $\mathrm{~T}$ \\
\hline $\begin{array}{l}\text { Printing, Copying \& Multi- } \\
\text { Function Devices }\end{array}$ & $26,372 \mathrm{~T}$ & $26,372 \mathrm{~T}$ & $\mathrm{~T}$ \\
\hline Waste Electronics & $73,570 \mathrm{~T}$ & $73,570 \mathrm{~T}$ & $\mathbf{T}$ \\
\hline Anti-Freeze & $3,187 \mathrm{~T}$ & $3,187 \mathrm{~T}$ & $\mathrm{~T}$ \\
\hline Oil Containers & $1,055 \mathrm{~T}$ & $1,055 \mathrm{~T}$ & $\mathrm{~T}$ \\
\hline Oil Filters & $10,687 \mathrm{~T}$ & $10,687 \mathrm{~T}$ & $\mathrm{~T}$ \\
\hline Paints and Coatings & $8,296 \mathrm{~T}$ & $8,296 \mathrm{~T}$ & $\mathrm{~T}$ \\
\hline $\begin{array}{l}\text { Pressurized Containers } \\
\text { (Non refillable) }\end{array}$ & $628 \mathrm{~T}$ & $628 \mathrm{~T}$ & $\mathrm{~T}$ \\
\hline $\begin{array}{l}\text { Pressurized Containers } \\
\text { (Refillable) }\end{array}$ & $104 \mathrm{~T}$ & $104 \mathrm{~T}$ & $\mathrm{~T}$ \\
\hline $\begin{array}{l}\text { Single Use Dry Cell } \\
\text { Batteries }\end{array}$ & $1,452 \mathrm{~T}$ & $1,452 \mathrm{~T}$ & $\mathrm{~T}$ \\
\hline Solvents & $4,176 \mathrm{~T}$ & $4,176 \mathrm{~T}$ & $\mathrm{~T}$ \\
\hline Hazardous Waste & $29,585 \mathrm{~T}$ & $29,585 \mathrm{~T}$ & $\mathbf{T}$ \\
\hline $\begin{array}{l}\text { Construction and } \\
\text { Demolition }\end{array}$ & $157,751 \mathrm{~T}$ & $220,047 \mathrm{~T}$ & $62,296 \mathrm{~T}$ \\
\hline
\end{tabular}

Table 7: Change in Diverted Tonnes.

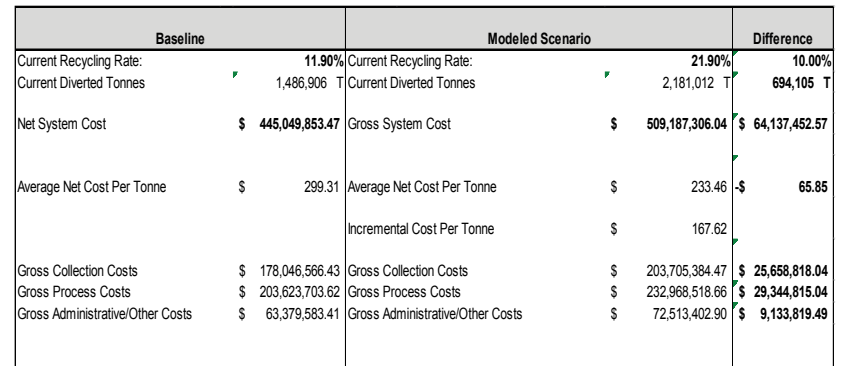

Figure 6: Model Output (Baseline vs Goal Scenario).

Thus, a $10 \%$ increase in IC\&I diversion (which would represent an increase of approximately 694,000 tonnes), may necessitate significant investments in collection, sorting and processing infrastructure. How much capacity (and what type of investments) is necessary is also largely contingent on where increases in diversion are likely to come from. For example, in the modeled scenario described in section 4.2, most of the additional tonnes come from paper based packaging and plastics. These materials are traditionally low cost and readily recyclable - thus, investments in additional MRF capacity are (relatively) low. Using the capacity estimates shown in Table 8 , under our modeled scenario, 281,000 tonnes of additional capacity would need to be added to the system. This would increase net system costs by approximately $\$ 23$ million dollars. However, should increases in diversion come from the hazardous waste stream (batteries, oil filters etc.) the potential infrastructural costs are enormous - based on best available data, the cost of managing one tonne of hazardous waste is more than $5 \mathrm{x}$ greater than managing an equivalent tonne of commingled packaging waste. Table 9 below provides estimates for both the existing capacity within the recycling system (by material stream) and what the additional per tonne infrastructural costs would be for exceeding that capacity. These figures have been calculated by taking the average cost per tonne for constructing, operating and maintaining new recycling/diversion facilities for the full range of IC\&I waste streams ${ }^{1}$ (Printed Paper and Packaging, Waste Electronics, Hazardous Waste and Organics).

\section{Which materials should we recycle?}

As noted in Lakhan's study on the costs of Blue Box diversion in Ontario, not all materials that can be recycled, should necessarily be ${ }^{1}$ Using data taken from IFO and Industry annual reports 
Citation: Lakhan C (2015) Modeling the Economic Impacts of Increasing Diversion in Ontario's Industrial, Commercial and Institutional (IC\&I) Sector. Adv Recycling Waste Manag 1:101. DOI: 10.4172/2475-7675.1000101

Page 9 of 10

recycled [26]. Differences in the cost of material management, as well as poorly developed end markets for certain materials, illustrates that some waste makes more sense to divert than others (when evaluated on economic merits). Based on the results from the cost modeling exercise in section 4.2 , there is a significant opportunity for the IC\&I sector to increase diversion at a minimal incremental cost by targeting materials that are traditionally considered as recyclable, i.e., paper, metals, cardboard and glass. A plastic recycling in particular represents a significant missed opportunity for IC\&I waste generators - with current recycling rates at less than 10\% for HDPE and PET packaging, even nominal increases in recovery rates would result in a significant increase in diverted tonnes. Table 9 below summarizes the list of materials that should be targeted for increased diversion within the IC\&I sector, based on the following criteria:

\section{1) Cost of material management}

2) Level or recyclability and

3) Available Capacity

It should be noted that the aforementioned materials in Table 9 are recommended using largely economic criteria. Increasing diversion while encouraging cost containment has long been a policy priority for Ontario (although their ability to achieve those goals simultaneously has largely been unsuccessful). While economically efficient diversion is certainly an important consideration, it largely ignores the environmental and social dimensions of diversion. Unlike packaging waste generated from the household sector, IC\&I waste includes a range of materials that pose acute risks to both the environment and human health. As such, it is almost by necessity that this material be managed and diverted from landfills, irrespective of cost. Who should incur these costs is the subject of intense debate -municipalities, waste generators and consumers grapple with how the costs of material management should be measured, who should manage it, and how costs should be recovered. The lack of accurate tracking and measurement of waste generated and diverted from the IC\&I sector further exacerbates these issues. If the sector cannot even reach consensus regarding how much waste they are generating, coming to an agreement on "who pays what" seems unlikely.

\section{Conclusion}

This study highlights the obstacles and opportunities for increasing diversion in Ontario's Industrial, Commercial and Institutional sector, specifically examining the infrastructural and operational costs of incremental increases in diversion. The findings from the cost model analysis found that increasing diversion in the IC\&I sector by $10 \%$, would increase recycling system costs by approximately $\$ 65$ million dollars. The cost of additional recycling infrastructure range from $\$ 64$ to $\$ 482$ a tonne, depending on the types of material diverted. Using the cost model for guidance, it is the recommendation of this study that printed paper, box board, PET and HDPE plastics should be targeted for increased recovery. Prioritizing these materials would allow the sector to increase overall diversion in the most cost effective way possible. However, as noted in section 4.4, provisions need to be made for the management of potentially hazardous materials generated from the IC\&I sector. The findings of this study suggest that while increasing diversion is certainly an important policy goal for Ontario, doing so will result in significant increases in material management costs - the magnitude of which may be sufficient to deter businesses from operating in Ontario. The province may also have endemic characteristics which make diversion more costly for IC\&I generators relative to disposal. In the absence of legislation that prescriptively

\begin{tabular}{|c|c|}
\hline \multicolumn{2}{|c|}{ Available Capacity } \\
\hline Capacity of Printed Paper and Packaging & $1,500,000 \mathrm{~T}$ \\
\hline Capacity of Organics System & $1,200,000 \mathrm{~T}$ \\
\hline Capacity of WEEE Recycling System & $160,000 \mathrm{~T}$ \\
\hline Capacity of MHSW Recycling System & $60,800 \mathrm{~T}$ \\
\hline Infrastructural Cost (\$/tons) \\
\hline Additional Infrastructure Cost PP\&P \\
\hline Additional Infrastructure Cost Organics & $\$ 82.14$ \\
\hline Additional Infrastructure Cost WEEE & $\$ 64.27$ \\
\hline Additional Infrastructure Cost MHSW & $\$ 432.98$ \\
\hline
\end{tabular}

Table 8: Available Capacity and Infrastructure Costs.

\begin{tabular}{|c|c|}
\hline \multicolumn{2}{|c|}{ Material } \\
\hline Paper & Non Ferrous Metals \\
\hline Corrugated Cardboard/Boxboard & Newsprint \\
\hline Ferrous Metals & PET Bottles \\
\hline
\end{tabular}

Table 9: Recommended Materials

bans from material going to a landfill, disposal will almost always be a cheaper alternative to recycling.

As noted in section 3.5, a potential limitation of this study is the relative paucity of data measured directly from the IC\&I sector. Figures regarding waste generation, recovery, material management costs and available capacity were largely estimated using data from residential recycling programs. While there is a methodological precedent for using data surrogates when primary data cannot be obtained, results should be seen as a "best guess" estimate. They are useful in providing directional insights into the system, but caution should be exercised when attempting to calculate exact dollar figures. The lack of data specific to the IC\&I system also highlights an opportunity for further research - to date, few studies have been able to specifically examine the IC\&I recycling system due to the dearth of sector specific information. Given the intersecting interests of public and private actors in gathering better information, researchers may have the opportunity to collaborate with local governments and companies to carry out research in this area. It is the recommendation of this study that these types of partnerships be explored, as the costs (in both time and money) of "going it alone" may be prohibitive to any one party.

Decision makers and policy planners need to make a conscious decision to prioritize what they want from the IC\&I system - if the focus (as it appears to be) is on the overall diversion rate, then supporting legislation needs to be put in place to both increase the coverage of who is covered by regulations, and increase the penalty for non-compliance. By limiting IC\&I legislation to large establishments, it is estimated that more than $70 \%$ of business operators fall outside the purview of existing legislation. Given that a significant percentage of IC\&I waste is being generated from these establishments, it seems prudent that they be included in the scope of who is required to operate waste diversion programs. The general argument against increasing the threshold to include small and medium sized establishments is that it would place an undue financial burden on businesses. If these establishments were directly responsible for the costs associated with managing the waste they generate (which as evidenced by this study, can be quite significant depending on the type of waste), they may face economic hardship resulting in closures or job losses. This is the stark reality facing the IC\&I sector in Ontario - you can either divert more waste at a significant cost, or adhere to the status-quo and fall further behind 
Citation: Lakhan C (2015) Modeling the Economic Impacts of Increasing Diversion in Ontario's Industrial, Commercial and Institutional (IC\&I) Sector. Adv Recycling Waste Manag 1:101. DOI: 10.4172/2475-7675.1000101

Page 10 of 10

other jurisdictions with respect to diversion performance. However, could an EPR program for the IC\&I sector be considered as a potential solution?

Ontario was one of the first jurisdictions in the world to implement EPR for printed paper and packaging waste [27-31]. However, for the IC\&I sector, the financial responsibility for the end of life management of material largely rests with waste generators. Exploring a system that transfers, either in whole or in part, the costs of waste management to packaging producers would be an important first step in making diversion in the IC\&I sector economically viable. It would also send a clear signal to packaging producers to design materials that can be readily diverted, or alternatively, incent them to support systems that can safely and effectively manage end of life waste.

While attempting to increase diversion in the IC\&I sector should continue be promoted as a policy priority in the province, Ontario faces an uphill battle. Significant amendments to existing regulation (i.e., expanding the scope of obligated generators, consideration of disposal bans, landfill levies, etc.) will be required if Ontario hopes to reach diversion goals. Tangent to that point, the economics of diversion relative to disposal will have to be given careful consideration. Diversion comes at a cost - both with respect to directly managing material and developing/maintaining infrastructure to accommodate for increased tonnes in the system. This cost is potentially quite significant, sufficiently so that it may not even be possible to achieve without packaging producers willing to bare the burden of some (or all) of that cost. The future of diversion in Ontario's IC\&I sector remains unclear, but the unrealized value of materials presently going to landfills (as well as the associated environmental and social harms) makes it impossible to ignore much longer.

\section{References}

1. Unruh, Gregory (2010) Earth. Inc. Using Nature's Rules to Build Sustainable Profits. Harvard Business School Press.

2. Vijay G, James K (2014) Opportunities for Ontario's Waste: Economic Impacts of Waste Diversion in North America. The Conference Board of Canada.

3. Statistics Canada (2012) Waste Management Industry Survey.

4. Ministry of the Environment (2013) Waste Reduction Strategy.

5. Maclaren VW, Yu CC (1997) Solid Waste Recycling Behavior of IndustrialCommercial-Institutional (ICl) Establishments. Growth and Change 28: 93-109.

6. Industry Canada (2014) Establishments by employment type and region.

7. Genivar (2009) Industrial Commercial and Institutional Waste 3R Strategy

8. Pirani S, Hassan A (2014) Solid waste management in the hospitality industry: A review. Journal of Environmental Management 145: 320-336.

9. Kibira D, Jain S (2011) Impact of Hybrid and Electric Vehicles on the Automobile
Recycling Infrastructure. Winter Simulation Conference, Phoenix, AZ, USA.

10. Das S, Curlee TR, Rizy CG, Schexnayder SM (1995) Automobile recycling in the United States: Energy impacts and waste generation 14: 265-284.

11. Counsell TAM, Allwood JM (2006) Desktop paper recycling: A survey of novel technologies that might recycle office paper within the office. Journal of Material Processing Technology 173: 111-123.

12. Price S, Pitt M (2012) The Influence of Facilities and Environmental Values on Recycling in an Office Environment. Indoor Built Environ 21:622-632.

13. Arevalo RN, Lyal C, Carrillo-Martinez MDC (2012) Re-use and recycling practices in a Columbian Hospital. AORN Journal 86: 791-797.

14. Dilly GA, Shanklin CW (1999) Waste reduction and recycling program in United States Army hospital foodservice operations. The American Dietetic Association 82nd Annual Meeting \& Exhibition, Atlanta, GA.

15. Hadjilambrinos C (1996) A Review of Plastics Recycling in the US With Policy Recommendations Environmental Conservation 23: 298-306.

16. Sardot, Tova (2012) Characterization of a cardboard recycling facility's plastic waste for beneficial use. Dissertations Paper: 4310.

17. Baeyens J, Brems A, Dewil R (2010) Recovery and Recycling of PostConsumer Waste Materials-Part 2. Target Wastes. International Journal of Sustainable Engineering 4: 232-245.

18. Ayres RU (1997) Metals recycling: economic and environmental implications. Resources Conservation and Recycling 21: 145-173.

19. Atherton $J$ (2007) Declaration by the metals industry on recycling principles. International Journal of Life Cycle Assessment 12: 69-70.

20. USEPA (2007) Municipal Solid Waste in the United States 2007 Facts and Figures. USEPA: Washington, United States of America.

21. Stewardship Ontario (2014) MHSW Annual Report.

22. Ontario Electronic Stewardship (2014) Annual Report.

23. Minister of the Environment (2011) Ontario Environmental Protection Act, Last Amended.

24. Ministry of the Environment (2004) Ontario Environmental Protection Act: Ontario Regulation 27404 Tax Matters - Notice Under Subsection 365.1.

25. Kelleher Environmental (2005) ICI Sector Consultation Session to Discuss Options to Achieve 60\% Diversion of Waste in Ontario.

26. Lakhan C (2015) Diversion, but at what cost? The economic challenges of recycling in Ontario. Resources Conservation and Recycling 95: 133-142.

27. Stewardship Ontario (2012) Blue Box GHG Report: Emissions Impact of Ontario's Blue Box Program.

28. Stewardship Ontario (2003-2014) Blue Box Annual Report.

29. Stewardship Ontario (2005-2014) Pay in Model.

30. Stats Canada (2011) Canadian Census.

31. Ministry of the Environment (2011) Ontario Environmental Protection Act: Ontario Regulation 10194 Recycling and Composting of Municipal Waste. 